\title{
A Conceptual Framework for Retro Marketing in Sport
}

\section{Zach Scola and Brian S. Gordon}

Zach Scola is a graduate teaching assistant in the Department of Health, Sport, and Exercise Sciences at the University of Kansas. His research interests include consumer behavior, retro marketing in sport, and sport fan ritualistic behavior.

Brian S. Gordon, PhD, is an assistant professor in the Department of Health, Sport, and Exercise Sciences at the University of Kansas. His research interests include consumer behavior/psychology, brand management of sport organizations, and fan loyalty.

\begin{abstract}
Retro marketing has become a staple in sport marketing practices. Teams and leagues are attempting to connect their fans to the past in a magnitude of ways. Despite the influx of retro marketing in sport, there has been no examination of it to date. This study examined the various usages of retro marketing in sport and through an inductive approach created a framework that categorized and broadly defined each usage. The five practical areas of retro marketing in sport were constructed: imagery, merchandising, venue, gameday promotions, and advertising. The authors shaped and framed retro marketing in sport through these five dimensions, as they encompassed the retro marketing practices examined and are often relied upon marketing elements. Further, the authors suggest multiple avenues for future research on this topic, including understanding a sport organization's usage of these practices and the impact they have on sport consumers.
\end{abstract}

Keywords: retro marketing, conceptual framework, nostalgia, brand management, strategic marketing

\section{Introduction}

It has become commonplace for sport teams and leagues to utilize retro marketing, often coined with phrases like "throwback" or "turn back the clock night." Despite the heavy usage of retro marketing in sport and increased attention in popular press, there has been minimal academic attention attempting to understand these practices. In the general marketing field, scholars have given the concept a requisite amount of examination, primarily involving the impact of producing retro brands. Brown, Kozinets, and Sherry (2003) defined retro branding as the relaunching of a product or service that is also brought up to contemporary consumers' standards. Reflecting on his retro marketing research, Brown (2013) described how he thought the "nostalgia boom" was just a fad, yet more than 15 years after beginning his research on retro marketing, it has grown and continued to be a successful marketing strategy. The sporting realm is no exception to the ever-growing usage of retro marketing as many professional teams and leagues have continued to incorporate retro elements into their overall marketing strategies.

Sport marketers have found a plethora of avenues to utilize retro marketing while teams and leagues also continue to implement retro marketing strategies. The ways in which teams can utilize retro marketing and remind their fans of the team's past are immense. Retro marketing can stretch from the intensive process the Toronto Raptors went through of redesigning their uniforms and court to resemble a former basketball team from Toronto called the Huskies for multiple games during the 2016-2017 season (Dator, 2016) to simply implementing throwback uniforms as alternate jerseys like the New York Mets and Pittsburgh Pirates did during the 2016 season (McGuire, 2016; Snyder, 2016a). Even when teams go through a redesign, they often consider retro elements. Both the Golden State Warriors in 2010 and the Toronto Maple Leafs in 2016 utilized aspects of their past in a complete logo and uniform redesign. The two teams went back to logos and colors that had been used in prior years and paid homage to their successful pasts (Creamer, 2016; 
“Golden State Warriors Unveil New Logo," 2010). Retro marketing is heavily utilized in imagery both temporarily with throwback uniforms and in more long term ways when teams conduct logo and jersey redesigns.

Throwback uniforms and logos appear to be the most commonplace utilization of retro marketing; this is likely due to the fact that each throwback uniform creates a new line of merchandise for their fans to purchase. There are numerous other avenues teams utilize with retro marketing in mind. One example is "turn back the clock" nights, which often use throwback uniforms and encourage fans to dress up as if they were in a different era; both the Seattle Mariners and a summer collegiate team, the Eau Claire Express, had turn back the clock nights during their 2016 and 2015 seasons, respectively ("Express Announce," 2015; Young, 2016). Additionally, teams do promotional giveaways that are retro, as the Chicago Cubs did by giving away 1916 jerseys during the 2016 season to commemorate their 100th year playing at Wrigley Field (Yellon, 2016). The Detroit Lions went as far as having a retro pricing promotion during the 2016 season, where they offered beer and hotdog pricing from the 1991 season ("Detroit Lions to feature," 2016). Another way that teams use retro marketing is by creating team hall of fames or museums such as the Green Bay Packers, Pittsburgh Steelers, New England Patriots, and numerous other NFL teams have to remind their fans of the team's past success and to allow the fans to reflect on it (Belson, 2014).

As the authors have detailed, retro marketing is heavily utilized by sport teams and leagues, yet it has received scant academic attention in the sport marketing literature. Sport marketing has become its own academic discipline, in part because of the incredible uniqueness that the sport product offers to managers and consumers (Coakley, 2007; Mullin, Hardy, \& Sutton, 2014) and it is necessary for sport marketing scholars to examine how the field itself differs from the general marketing context. Sport is unique from general marketing in that it cannot be marketed like a general good or service (Coakley, 2007), and the most unique feature may be how fans can develop an irrational passion for their team that normal consumers do not demonstrate (Hoye, Smith, Nicholson, \& Stewart, 2015). Beyond this irrational passion from consumers, a sporting event differs from traditional goods and services in its unpredictability, simultaneously consumption and production, and in the subjective experiences from fan to fan as no two fans have the exact same experience (DeSensi \& Rosenberg, 2010). These factors together make marketing a sporting product distinct, but additionally offer extensive avenues through which sport marketers can implement retro into their marketing plan.

To this end, scholars have argued that nostalgia is an under researched area in the sport realm (Gordon, 2013). We also know that nostalgia plays a prominent role in impacting consumer attitudes and intentions in the general marketing context (Merchant \& Rose, 2013; Pascal, Sprott, \& Muehling, 2002). Given the fact that sport consumers tend to join social categories (i.e., become fans of a specific team) that will enhance their own self-concept (Tajfel \& Turner, 1979) as well as associate them with successful teams in an effort to reap self-esteem benefits (Cialdini et al., 1976), it stands to reason that a salient and successful sport team brand heritage may be a considerable marketing asset. Further, an in-depth knowledge of team history has been found to be one of the hallmarks of the allegiant sport consumer (Funk \& Pastore, 2000) and a central team brand association along with nostalgic feelings (Bauer, Stokburger-Sauer, \& Exler, 2008; Gladden \& Funk, 2002; Ross, James, \& Vargas, 2006). As retro marketing is so often utilized in sport and past research has hinted at the immense potential of nostalgia as a sport marketing asset, it is important for scholars to have a conceptual framework that explains retro marketing in sport in detail. Therefore, the purpose of this paper is to use an inductive approach to create a conceptual framework of what comprises retro marketing in sport and categorize these practices into broad, established themes that encapsulate sport marketing retro practices.

\section{Theoretical Framework}

In order to understand retro marketing in sport, it is first important to understand the theoretical underpinnings of retro marketing from past literature. In the field of sport management, it is important that we conduct theory-based and theory-building research (Doherty, 2013). The theory that was utilized to understand the potential impact of retro marketing in sport on the consumer was the Stimulus-Organism-Response framework ( $\mathrm{S}-\mathrm{O}-\mathrm{R})$, which describes the way in which a stimulus, which can include an aspect of marketing or environmental factors (Bagozzi, 1986), impacts the consumers feelings and decisions. Beyond the S-O-R framework, the authors felt it was important to review the literature on nostalgia and retro marketing in sport.

\section{Stimulus-Organism-Response Framework}

Mehrabian and Russell's original S-O-R framework considered the environment the stimulus, primary emotional responses the organism, and behavioral 
responses as the response (Mehrabian \& Russell, 1974, as cited by Vieira, 2013). The three aspects of this framework have been used in numerous studies on consumer research. In this model, the stimulus is considered the factors that impact the internal states of the consumers and influence the individual's decision making (Eroglu, Machleit, \& Davis, 2001). Next, the organism is the "internal processes and structures intervening between stimuli external to the person and the final actions, reactions, or responses emitted. The intervening processes and structures consist of perceptual, physiological, feeling, and thinking activities" (Bagozzi, 1986, p. 46). Last, the response is the ultimate decision or outcome that an individual comes to (Chang, Eckman, \& Yan, 2011). Using the S-O-R framework, consumer behavior research typically examines approach behaviors as they are the positive outcomes that marketers hope to see out of their consumers (Chang et al., 2011). The original framework considered aspects like color and temperature of the stimulus and focused on pleasure arousal and dominance as characteristics describing the emotional response or organism (Vieira, 2013). Exploration, affiliation, and preference comprised the original responses under examination while many other responses have been considered in studies that have adapted this model, primarily examining consumer preference behaviors (Vieira, 2013).

Specifically, the S-O-R framework has been used to examine consumer emotions (Sherman, Mathur, \& Belk Smith, 1997), traditional and online retail atmospheres (Chang et al., 2011; Eroglu et al., 2001), hospitality and nostalgia (Hunt \& Johns, 2013), and the atmosphere of major sporting events (Uhrich \& Koenigstorfer, 2009). This framework has been used in a variety of research settings involving consumer behavior and has been successful in encapsulating the behaviors of the consumers (response) based on the marketing practices (stimulus). Hunt and John (2013) suggested the positive emotions primarily evoked from nostalgia acting as a stimulus operate as approach behavior, thus creating positive marketing outcomes for the organization. The fact that S-O-R has been effective in understanding consumer behavior and incorporating retro marketing into a multitude of marketing tactics is a distinct example of adapting the stimulus. The authors deemed this framework appropriate to explain the underlying mechanisms of how retro marketing operates in the sport environment. Before examining the retro marketing practices in sport, it is important to understand the literature on nostalgia and retro marketing in sport.

\section{Literature Review}

\section{Nostalgia}

The definition and understanding of nostalgia has drastically changed since it first appeared as a medical term in the late 1600s (Batcho, 2013). Nostalgia has progressed from being considered a physical sickness, to a mental illness, and now to a feeling of longing for the past (Batcho, 1995; 2013). Others have found and claimed that nostalgia is positive for individuals, yet may be brought on by negative feelings such as loneliness (Sedikides, Wildschut, Arndt, \& Routledge, 2008; Wildschut, Sedikides, Arndt, \& Routledge, 2006).

Nostalgia has been considered in the traditional marketing literature to be an effective strategy to positively impact their consumers.

Numerous studies have considered what impact a retro marketing practice may have on consumers and most consider the influence of nostalgia. Pascal et al. (2002) found a positive correlation between nostalgic feelings for an advertisement and improved attitudes towards the advertisement. Scholars have found that consumers have different types of effective nostalgia that can be tapped into via marketing schemes and have specifically found that drawing on a consumer's past group memberships may be exceptionally effective (Sierra \& McQuitty, 2007; Zhao, Li, Teng, \& $\mathrm{Lu}, 2014)$. Interesting for the sport context, Merchant and Rose (2013) found that vicarious nostalgia could impact consumers when exposed to marketing practices paying homage to the past. This concept means that individuals can feel nostalgic about a time before their existence. Brown (2013) contends the terms retro and nostalgia are related but not synonymous. To specify, retro marketing utilizes modern materials and technology performance wise, but hints at the past, whereas nostalgia marketing would be simply recreating an old practice. For example, when a team uses a retro uniform or a retro give away item, the performance and quality of the item is up to date and the imagery or coloring is meant to elicit the past. If a team were to simply reuse an old advertisement, or giveaway a jersey that was created in the 1970 s and has not been updated, this would be nostalgic marketing. Based upon the findings from this study, the authors have deemed the practices utilized by sport marketers to be retro, not nostalgic, marketing. Retro marketing has become extremely prevalent in the sporting world and similar to traditional marketing scholars, most of the research has focused on the impact of nostalgia.

\section{Retro Marketing in Sport}

Over the last 20 years, marketing scholars have examined retro marketing and many claimed the 
heavy reliance on it was due to consumers' increased nostalgia from the fin de siècle effect (Stern, 1992). The fin de siècle effect explains that there is cultural anxiety about the experiences involving discontinuity that is associated with the end of an era. The usage of retro marketing was considered to be a fad that would likely fade away at the turn of the century (Brown, 2013). Retro marketing has been investigated in the traditional marketing literature and deserves the same attention in the sport management field.

Sport management scholars have examined retro marketing practices and nostalgia in past literature. First, Gladden and Funk (2002) developed a team association scale that was utilized to examine how impactful numerous associations of an individual's favorite team were. The scholars found nostalgia was a central brand association among sport consumers and they attempted to determine how memories of their favorite team impacted their fandom. The idea that teams and leagues may try to create nostalgic feelings within their fan base makes sense and is supported by Funk and James (2006), where they found nostalgia to be one of the associations most related to allegiance in fans. Another scale was developed to measure brand associations with professional sport teams and this one included team history as an association (Ross et al., 2006). Bauer et al. (2008) created a model to examine which aspects of brand image impacted fan loyalty and treated nostalgia as an experiential benefit. While none of the aforementioned work centered on retro marketing practices, it is evident that nostalgia and team history play a vital role in sport team branding efforts.

Seifried and Meyer (2010) examined NFL and MLB stadiums and concluded "that sport facilities hosted attempts to create nostalgia related feelings by offering structures within the building which mythologize the past through the promotion of past heroic achievements and the embracing of authentic values (i.e., hall of fame, museum, monuments, statues, produced videos)" (p. 69). Other studies have found that nostalgia plays a role in sport heritage overall (Ramshaw \& Gammon, 2005) and that it was the main element behind the experience of an extreme traveling Australian Football League fan club (Fairley, 2003). Much like the sport management literature, Gordon (2013) noted that nostalgia was an under researched aspect of sport tourism and that nostalgia may be vitally important to a sport fan's attraction to these sites. Scholars have also created an in-depth model for nostalgia in the sport tourism domain that distinguished sport from traditional venues (Cho, Ramshaw, \& Norman, 2014). This model classified nostalgia around sport tourism into four segments (experience, socialization, personal identity, group identity) and expressed the importance of each type of experience as well as suggested a great deal of future research. Additionally, Stride, Wilson, and Thomas (2013) examined statues associated with the European Football teams and found that one of the primary motivations behind constructing these statues was to evoke nostalgia in their fans. From an examination of the related literature and organizational practices in the realm of retro marketing, retro marketing in sport can be defined as a strategic sport marketing practice that connects consumers with a former historical era, oftentimes connected to their team or league's past.

The authors utilized a general inductive approach, as the conceptual framework was not created from a preconceived theory but rather from the numerous practical examples in sport and construed into a model (Thomas, 2006). A general inductive approach is effective at taking raw data, grouping it by similarities, and developing a framework that structures the raw data (Thomas, 2006). Thus, an inductive approach was deemed appropriate given the bevy of different strategic retro marketing practices utilized by sport organizations and the lack of an existing framework to classify the practices. The authors searched for and examined numerous examples of retro marketing in sport and categorized them into broad groups. Then, after further examination, they created subgroups for each (Thomas, 2006). To uncover practical examples of retro marketing in sport, the authors utilized a bevy of resources, including academic literature and industry examples. This included an extensive search of relevant academic articles throughout Google Scholar, general google searches, examined numerous sport websites (i.e., espn.com, sportlogos.net, bleacherreport.com), scoured the various public communication outlets (websites, Twitter, Facebook, Instagram, etc.) of professional (primarily NBA, NFL, NHL, MLB, MLS, and English Premier League teams) and collegiate (primarily Division I, FBS schools), and examined Twitter for examples. Using these databases, the authors utilized terms such as "retro," "throwback," "retro promotion," "hall of fame," and "historical" to guide their initial collection of retro examples.

In the following section, the authors have detailed what they discovered when examining retro marketing in sport through a general inductive approach. This examination led the authors to the five practical areas of retro marketing in sport (see Figure 1). Aligning with the authors' methodological approach, the following section is broken down into each theme. For each theme, a general description of each marketing 


\section{Five Practical Areas of Retro Marketing in Sport}

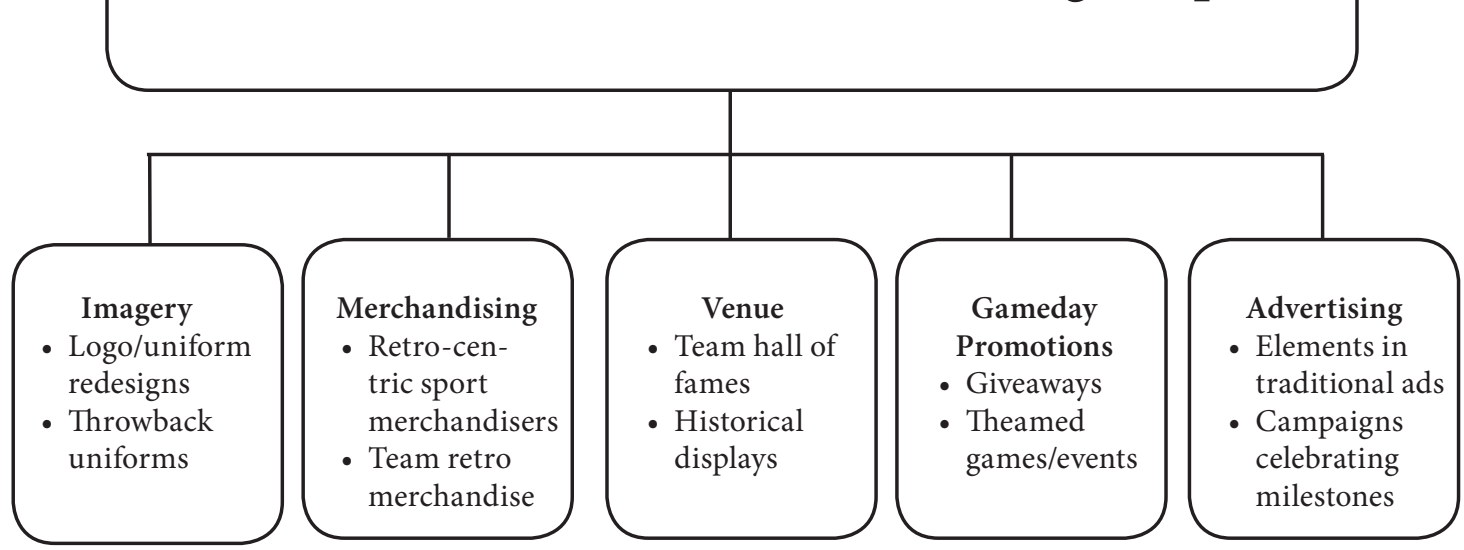

Figure 1. Five Practical Areas of Retro Marketing in Sport

practice is provided. Further, numerous practical examples of how retro marketing is utilized in the overall marketing practice is detailed. The five practical areas that emerged from the analysis are: imagery, merchandising, venue, gameday promotion, and advertising.

\section{Five Practical Areas of Retro Marketing in Sport}

\section{Imagery}

Sport marketing practitioners utilize retro marketing in their imagery in multiple ways, primarily utilizing throwback uniforms and in-brand redesigns. As brand imagery can be one of the most prevalent features in a consumer's overall perception and opinion of the brand, it is reasonable that retro marketing is utilized in imagery (Park, Eisingerich, Pol, \& Park, 2013). The most simple and heavily implemented way is when teams and leagues introduce throwback uniforms, names, or courts during their games. Numerous teams have employed throwback jerseys including the Green Bay Packers and Miami Dolphins during the 2015 NFL season (Lukas, 2015), the Golden State Warriors and Sacramento Kings in the NBA, who utilized a throwback court along with a throwback jersey during the 2015-2016 season (\#FlashbackFriday games and final regular season home game, 2016; Whitaker, 2015), and by the New York Mets and Pittsburgh Pirates of the MLB, who used throwback jerseys throughout the 2016 season (McGuire, 2016; Snyder, 2016a). Before the 2016 season, the University of Miami football team had a launch party for their "Legend of the U" throwback jerseys, which were a tribute to the jerseys the team wore in the 1980s (Ducey, 2016). For the 2017-2018 season, Liverpool of the English Premier League featured an orange alternate jersey considered a throwback to their 2000-2001 season, and the Tottenham Hotspurs slightly altered their logo to resemble the one they used from the late 1950s until the early 1980s ("Premier league kits," 2017). The usage of throwback jerseys has been extensive in professional sports as of late and includes leagues' usage of retro marketing. In 2013, the NBA had adidas unveil seven throwback jerseys as a part of their Hardwood Classics series (Young, 2013). Beyond temporarily using retro aspects in uniforms, logos, and courts, teams have incorporated retro into their logo and jersey redesigns.

As many teams are often redesigning their imagery, for numerous reasons, some have relied on retro marketing factors in the process. Two examples include the previously mentioned redesigns by the Golden State Warriors and the Toronto Maple Leafs. When the Warriors conducted a redesign of their logo and uniforms in 2010, they went back to a color scheme that they had not used since 1997 and created a primary logo that was similar to the logo they used from 1966-1971. The Warriors Team President explained how the redesign was using retro elements: "This new logo pays homage to our organization's rich history, and unique standing in the Bay Area sports community" (“Golden State Warriors Unveil New Logo," 2010, 
para. 3). Another team who made changes to their logo and uniforms with retro marketing in mind was the Toronto Maple Leafs. The Maple Leafs redesigned their logo for the 2016-2017 season that was incredibly similar to their logo from the 1963-1967 season. Specifically, the new Maple Leaf's logo had 17 veins to mark their inaugural season (1917-1918), 31 points to represent the 1931 season when they won the Stanley cup and opened the Old Maple Leaf Gardens, and the top half of the leaf had 13 veins to represent the teams 13 Stanley Cup victories, all of which pay homage to their history and past success (Creamer, 2016). The Maple Leafs and Warriors are great examples of teams who have ingrained retro aspects into their logo and uniform redesign, and this reliance on retro elements for the team's logo and jersey redesign add credence to the importance of retro marketing in sport. The authors have deemed throwback jerseys and logo and jersey redesigns utilizing retro marketing elements as ways that sport teams and leagues use retro marketing in their imagery. A sport marketing activity that often implements retro imagery is merchandising, as teams and leagues sell a great deal of merchandise with retro marketing in mind.

\section{Merchandising}

In 2005, sportswear sales were estimated to be 61 billion dollars in the United States, making merchandising a great avenue for sport marketers to implement retro (Chi \& Kilduff, 2011). With the influx of retro marketing in general business and sport, there have been companies created simply on the concept of retro branding. Mitchell \& Ness and Ebbets Field Flannels are two prominent and successful retro apparel companies and a great deal of their products are sports apparel ("About us", n.d.; "Our story", n.d.). There may have been a true "nostalgia boom" as past scholars have suggested if you consider Mitchell \& Ness and their meteoric rise in sales over a small two-year window between 2000 and 2002, as they saw an increase from $\$ 2.8$ million to $\$ 25$ million in sales (Century, 2003). In fact, by 2000, all four of the major sport leagues (NFL, MLB, NBA, and NHL) had granted Mitchell \& Ness licenses to create merchandise lines and produce their official retro jerseys (Our story, n.d.). As companies are striving and existing through retro brands alone, it is no surprise teams and leagues are also heavily invested in promoting and selling their retro merchandise.

Sport leagues and teams are promoting a great deal of retro merchandise through their online sales departments. The Green Bay Packers have a "throwback" section of jerseys for which Mitchell \& Ness is one of their two featured brands ("Green Bay", n.d.). The
New York Rangers have a similar throwback section on the NHL shop ("New York", n.d.). Additionally, an official soccer jersey supplier that features teams from the English Premier League contains a section that is called retro soccer gear (Retro Soccer Gear, n.d.). Merchandising differs from teams utilizing throwback uniforms in the sense that these are items available for purchase by consumers and not necessarily worn by players. A team may very well use the same throwback jersey to change their imagery by having their team wear it and in their merchandising as they sell it to fans, but it is the action involved with the jersey (team wearing it or selling to consumer) that differentiates the two. Because merchandising generates a significant amount of money for these teams and leagues (Liu, 2011), and it is apparent that teams and leagues are using retro marketing in their merchandising practices, it must be included in the practical areas of retro marketing in sport. Another effective area of retro marketing that has been utilized in sport involves the physical space that the team plays in.

\section{Venue}

The physical space that an organization offers in the service industry can be very influential on the consumers (Bitner, 1992; Wakefield \& Blodgett, 1994), and for sport teams, the physical space falls within their venue. Many teams are using aspects of their stadium or arena to promote their past and remember the successes they have had. Over the last few years, many NFL teams have begun to add historical displays or even their own hall of fames to their stadiums (Belson, 2014). In 2012, the Green Bay Packers had their one millionth visitor to their Packers Hall of Fame Museum, which has been a part of their stadium, Lambeau Field, since 2003. The Packers were the first to have their own hall of fame museum, but many teams have begun to follow suit (Belson, 2014). The concept of hall of fames extends beyond the United States to the Australian Football League that in 1996 began their league hall of fame, which consisted of 251 members by 2014 . Through other historical displays, many teams remember their past players, sometimes using a ring of honor like the Washington Nationals and Vancouver Canucks ("Frank Howard to be inducted," 2016; Staff Writer, 2016) or by retiring numbers and displaying them around the stadium or arena as the Boston Celtics, who have retired 21 jersey numbers ("Should Boston Celtics un-retire," 2015), and the Duke basketball team have ("Duke to retire," 2007).

Another prominent historical display that teams utilized to celebrate past success is with statues of players and coaches around their stadiums. In 2017, the Cincinnati Reds honored Pete Rose with a statue 
outside of Great American Ballpark, making him the eighth past star to be honored that way (Associated Press, 2017) and English Premier League power house Arsenal has five statues honoring 3 past players, 1 manager, and even 1 vital member of their staff ("Five statues of Arsenal Legends," 2017). Another way that many teams utilize retro marketing in their venue is by putting banners up commemorating past team successes, whether that's winning the division, conference, or championship. When teams utilize a ring of honor, hang retired jersey numbers, or put up statues of past greats, they are celebrating the success of their past players as well as the heritage of their brands, and many teams are using this form of retro marketing at their venues. The immense usage of retro marketing in and around teams' venues created this practical area. The fourth practical area considered the promotions during games.

\section{Gameday Promotion}

Teams utilize retro marketing in their promotions in a few different ways. The first way is very simple and involves using retro marketing in their gameday giveaways; the items given away can vary greatly. The Georgetown basketball team gave away a bobble head of former great Allen Iverson at a game in the 2016-2017 season (Chippin, 2016) and the Phoenix Suns gave away a tank top with their retro logo at one game during the 2016-2017 season (Emerick, 2016). During the 2016 MLB season, the Cleveland Indians gave away a retro jersey, the Philadelphia Phillies gave away retro socks, the Reds gave away a bobble head of recent Hall of Famer Ken Griffey Jr., and the Dodgers gave away hall of fame pins to celebrate their past hall of famers, and this is just a sampling of the retro giveaways in the MLB (Snyder, 2016b). In addition to celebrating the past with a giveaway, teams often opt to celebrate the past during a specific game or games throughout a season.

Teams utilize retro marketing by celebrating their past through a promotional night or specific game. Teams can do this by having a special game to celebrate the anniversary of a championship as the Portland Trailblazers did. For one game in the 2016-2017 season, the Trail Blazers brought back members of their championship team from 40 years ago and offered an autograph session and photo opportunity for fans as well as had an on-court tribute to the championship team during half time ("Trail Blazers flashback to 1977," 2017). Another type of promotional night that teams often participate in is called turn back the clock night, ranging from the Seattle Mariners to the Eau Claire Express, a summer collegiate team ("Express Announce," 2015; Young, 2016). For turn back the clock nights, teams will often wear retro uniforms, sell retro merchandise to the fans, and encourage fans to dress like the era being celebrated. Some teams have brought retro pricing into their promotional games as well, including the Detroit Lions, who did retro prices on their concessions in the 2016 season and the Kansas City Royals, who offered retro pricing days on their tickets during the 2009 season ("Royals Retro Pricing; "Detroit Lions to," 2016). Numerous teams are incorporating retro aspects into many of their gameday promotions, primarily with their giveaways and events. The last practical area that the authors discovered was advertising

\section{Advertising}

The correct advertising message can communicate information about a team, develop or change its image, create an association of emotions, and eventually precipitate behavior of consumers (Mullin et al., 2014). Further, sport marketers have successfully implemented retro into their overall marketing plans and more specifically, into the content of their advertising messages. There are two primary ways that teams implement retro marketing into their advertising campaigns. The first involves including aspects of their past in a normal advertising campaign or any of their traditional advertisements, and the second is when leagues or teams create an advertising campaign celebrating a milestone. Teams can draw on their past in general advertising campaigns; one example is the Phoenix Suns with their \#WeArePHX campaign, as they focus on their connection to the valley since 1968 (Fincher, 2015) and promoted inducting Steve Nash into their Ring of Honor (Sara, 2016). Another example is the Boston Celtics who put out a short ad that promoted past legends Larry Bird and Robert Parrish as well as paid homage to their $17 \mathrm{NBA}$ championships (JR, 2012). The leagues are also able to get involved in retro advertising, as the NBA did when they opened their 2011-2012 season with an ad called "NBA Forever" on TNT that mashed up highlights of current and former players to make it appear as if they were playing together (Klopman, 2011). Additionally, the Maple Leafs are one of the original six teams, which means they are celebrating their 100th year in conjunction with the founding of the NHL. This leads to the second way teams have been using retro marketing in advertising.

Many teams and leagues have created advertising campaigns focused on anniversaries-lately many have celebrated their centennial. The Chicago Cubs celebrated 100 years at Wrigley throughout the 2016 season (Neveau, 2015), the Pac-12 celebrated their centennial in 2015 ("100 years of champions," n.d), the 
NHL and Toronto Maple Leafs both celebrated their centennial during the 2016-2017 NHL season (Mirtle, 2016; NHL Public Relations, 2016), and in 2013 US Soccer celebrated their centennial (Bell, 2013). There are numerous ways that these teams and leagues have celebrated their milestones. The Toronto Maple Leafs used an advertising campaign called "Stand Witness" that included multiple social media campaigns and a short advertisement that follows an elderly man watching old clips of the team winning championships in the 1960s (Mirtle, 2016). The Pac-12 advertised their centennial with the 100 years of champions campaign that included creating all-century teams and many centennial centered videos ("100 years of champions," n.d). In a related fashion, US Soccer had a centennial week that they celebrated in New York where they originally were headquartered and promoted their milestone with a \#100Years hashtag on Twitter (Bell, 2013). Celebrating milestones has become a very popular way for teams and leagues to use retro marketing. When utilizing retro marketing in their advertising campaigns, teams are likely tapping into the nostalgic feelings of their consumers, which has been found to be effective in marketing (Pascal et al., 2002; Sierra \& McQuitty, 2007). Advertising completes the five practical areas of retro marketing in sport as it covers the remaining utilizations of retro marketing in sport.

\section{Discussion and Directions for Future Research}

Scholars should be able to rely on this framework and use it in their empirical research on retro marketing in sport. The authors believe this study should be the first step in a long line of research on retro marketing in sport and have suggested the following avenues for future research, tailored to the importance of continuing this research in the sport management literature.

\section{Retro Marketing and Sport Organizations}

The authors have detailed many of the ways in which teams and leagues utilize retro marketing and future scholars should research how and why these sport organizations choose retro options. One study examined fans' feelings about logo redesign for two NBA teams, the Utah Jazz and Golden State Warriors, and found highly identified fans were less accepting of logo redesigns than low or moderately identified fans (Ahn, Shu, Lee, \& Pederson, 2012). Despite the negative attitude towards a redesign, highly identified fans purchase intentions significantly increased with the new logo (Ahn et al., 2012). The idea that a fan may have a negative attitude about a new logo yet have an increased desire to purchase merchandise may show how strong their connection to the team truly is. Further, this particular study did not focus on the incorporation of retro elements into a logo redesign. Therefore, this could be an added dimension to explore that may present some further explanatory power in understanding what drives sport consumer attitudes and intentions. Another potential research avenue would be the motivations behind a team selecting to associate with their past. The Golden State Warriors are a great example of a team who used a great deal of retro elements in their logo and jersey redesign, but in Ahn et al.'s (2012) study the fans had a negative attitude towards the change. A qualitative study with the sport marketing decision-makers would be helpful to garner an understanding of the how and why behind teams and leagues utilization of retro marketing. These studies should be conducted with marketers of teams who are responsible for developing and implementing retro marketing strategies, with those individuals involved in merchandise decisions at the league level (i.e., those who work with Nike in the NFL or adidas in the NHL), and with apparel companies, especially those whose core business are centered around retro (i.e., Mitchell and Ness), as they will have the greatest insights into retro marketing practices in sport. Further, some boundary conditions could be established regarding when it is best to incorporate retro elements into a logo or uniform redesign. It will be interesting to compare teams with different backgrounds of success, differing market sizes, and past logo and jersey designs in regards to their retro marketing usage and success.

When it comes to imagery, merchandising, gameday promotions, and advertising, teams must be selective of when and where to use retro marketing; it may be dependent upon their history and past decisions. Therefore, a line of inquiry could operationalize a bevy of organizational characteristics (sport level, market size, presence/lack of historic success, logo/brand history, conference/division) and link these characteristics to the retro marketing strategy and tactics. Ironically, some of the most historically successful teams (Los Angeles Lakers, New York Yankees, and Chicago Blackhawks) have gone through minimal jersey and logo changes and therefore should have fewer retro marketing avenues at their disposal. Conversely, teams like the San Diego Padres have undergone multiple changes to their primary and alternate logos over the course of their history and utilize these "retired" logos in their retro marketing efforts in multiple ways. Examining what this means for an organization will likely be meaningful for this field of research and help decipher whether teams with a past historic success or teams who have simply changed their logos and 
uniforms more often have greater retro marketing potential. Also, it will be interesting to learn which type of team, historically successful or multiple redesigns, relies on retro more heavily. There are many ways that teams and leagues choose to utilize retro marketing and it is impacted by not only the success of the organization, but the past choices they have made.

The most interesting practical area that teams may use retro marketing in is the venue, as the decisions regarding what is worthy of being marketed vary from team to team. Much of the variation in the utilization of retro marketing in venue has to do with the team's past success. The Boston Celtics have retired so many numbers for their past greats that they almost need to un-retire numbers to hold a team ("Should Boston Celtics un-retire," 2015), whereas the Miami Heat have a Michael Jordan Bulls jersey up in their rafters and the Colts have an "AFC Finalist" banner up (Hurley, 2015). Each team has a specific venue and can make unique choices with what type of historical displays and types of retro marketing they can put up around the venue. Further, the venue itself may act as a retro marketing tool dependent upon the age of the facility, design features, and event history. For example, Camden Yards, opened in 1992, flaunts a design that incorporates modern amenities into a facility that is meant to appear as though it was built during a prior era, bucking the trend of facility design at the time (Kamin, 2017). Interviewing sport practitioners who operate and make marketing decisions in facilities that fit the description above could lend some insight into not only how they try to capitalize on retro marketing in their facility but also the challenges they face due to facility limitations.

As sport leagues grow in success and popularity they expand and create new teams quite often, and these teams do not have many retro marketing avenues. Despite the lack of history, some relatively young sport teams have introduced "retro" material to their organization. The previously mentioned Toronto Raptors entered the NBA in 1995, and although they have been through a major logo and uniform redesign they utilized Toronto Huskies imagery for multiple games this past season (Dator, 2017). What is unique about the Raptors usage is they have no connection to the Toronto Huskies, as the Huskies were a one year member of a basketball league that was around before the NBA. Similarly, the Tampa Bay Rays have been engaging in retro marketing tactics with the incorporation of "fauxback" uniforms and imagery. Given their lack of extensive history in the MLB, the Rays have endeavored to manufacture nostalgic feelings among their fan base by utilizing uniforms that have a 1970s-era appearance even though the club did not exist (Hill, 2017; Knapel, 2012). The Jacksonville Jaguars sell "vintage" merchandise through the NFL shop, yet they were established in 1995 ("Jacksonville Jaguars", n.d.). Some may argue that the previous examples are not retro because the teams do not have enough of a past, but these organizations still rely on retro practices and to discover what makes something retro, scholars must examine the consumers.

\section{Retro Marketing and Sport Consumers}

Beyond just establishing the general effectiveness of retro marketing practices, it is useful to determine which practical areas are the most and least effective. Additionally, this research will likely be most useful to sport practitioners, as it should have numerous practical implications for the field. This is one area that sport management scholars can not only adapt from the general marketing literature as much of the empirical research could be borrowed from past retro marketing scholars, but the opportunity also exists to understand how retro marketing may operate differently in the sport realm and build sport-specific theory (Doherty, 2013).

A majority of research on retro marketing has focused on the impact of nostalgia in advertising. Scholars have discovered that nostalgia can evoke positive emotions and intentions, but also that brands must update the material and not simply revive an old brand (Cattaneo \& Guerini, 2012; Pascal et al., 2002; Phau \& Marchegiani, 2011; Sierra \& McQuitty, 2007). When it comes to sport, there are many other avenues scholars can examine. The extreme passion and team identification that make sport consumers unique could make nostalgic feelings more prominent (Coakley, 2007). Sierra and McQuitty (2007) discovered that individuals who had favorable feelings about their group memberships were susceptible to nostalgic feelings.

Further, these scholars suggested sport franchises were a venue that could easily draw on their consumer's nostalgia proneness. Sport management scholars have treated nostalgia or team history as a prominent brand association (Bauer et al., 2008; Funk \& James, 2006; Ross et al., 2006) and if nostalgia is an aspect sport consumers consider when following their favorite team, it is likely instrumental in sport marketing. Sport consumers' extreme passion and team identification may impact nostalgic feelings.

Given this distinct psychological connection, nostalgia's impact on sport consumers may manifest itself differently than in the general marketing context. Therefore, nostalgia will likely be influential in sport and could be examined through all five of the practical areas and compared. As nostalgia is a yearning for 
the past and can impact consumers cognitive and emotional factors related to the past (Holbrook, 1993; Sierra \& McQuitty, 2007), any retro marketing should make a point of connecting the fans to the past. Using past imagery in a redesign or merchandise will connect fans to the past, and putting up banners around the venue will remind fans of the teams past success. Teams can also use past players with a bobble head giveaway or in an advertisement, which should remind their fans of when that player was a part of the team. Nostalgia's impact should be empirically examined through all practical areas whereas the lived history that a team presents may create more ways for nostalgia to be impactful.

To examine sport consumers' reactions to retro marketing, there are numerous theoretical frameworks that could be utilized. As discussed earlier, $\mathrm{S}-\mathrm{O}-\mathrm{R}$ theory is effective because retro marketing is impacting the stimuli and examining sport consumers' response to these stimuli would be important in measuring the effectiveness of these practices. Another way to examine consumers and the influence of retro marketing may be via sport fan classifications such as the Psychological Continuum Model (Funk \& James, 2001) or the conceptual classification of sport fans (Hunt, Bristol, \& Bashaw, 1999). Both of these frameworks distinguished fans based on their level of psychological connectedness to the team and it would prove interesting to examine how different types of fans react to each of the five practical areas of retro marketing in sport.

Additionally, it would be useful to examine sport consumers, retro marketing, and socialization into fandom. There may be a connection between how one is socialized into fandom and the way retro marketing practices impact them. Scholars have found that fathers and one's hometown are two factors that were prevalent in socializing an individual into their fandom (James \& Kolbe, 2000). James (2001) found that children as young as five years old may be able to cognitively display commitment to a sport team. These factors, the conditions by which and when one becomes a fan, along with how long an individual has been a fan, may prove worthwhile to examine regarding the impact of retro marketing. One may expect that a lifelong fan would be more impacted by nostalgic feelings than an adult who recently became a fan of the same team. When considering the impact of nostalgia on retro marketing in sport, the way in which one is socialized into becoming a fan may be very influential on the impact of retro marketing practices.
A sport team has an impact on consumers that other brands cannot offer and that is the concept of the lived experience fans receive through being a fan of a team. Sport teams are constantly changing unlike typical brands; the prestige and favor, or brand equity, of a team relies, in part, upon the uncontrollable on field success or failure (DeSensi \& Rosenberg, 2010). Conversely, a traditional goods brand can control the aspects that influences their consumers' brand equity (Keller, 1993). Despite not always being old enough to experience an era of a team, sport fans may be able to relate to this time through vicarious nostalgia and still look fondly on a past that they did not live through (Merchant \& Rose, 2013). As mentioned previously, the irrational passion that fans feel towards their favorite teams (Coakley, 2007) likely enhances nostalgia's impact, as they may have more memories to connect to. Since it is critical to the field of sport management to conduct theory building research (Doherty, 2013) and the research on retro marketing in sport is in its infancy, it would be compelling to investigate if the lived experience of sport fandom makes nostalgia even more influential than in traditional, mainstream retro marketing.

Another way sport scholars can expand this research is to examine what makes something retro, as there are many options teams use for which it would be beneficial to examine what the consumer considers to be retro. Often teams and leagues simply bring back old logos or jersey designs and consider the merchandise or imagery to be retro. The consumer's perception will be important though, especially considering a team with a short history that wants to tap into the retro market. One example is the Tampa Bay Rays and the retro jersey they claimed was from a time period nearly twenty years prior to when their team formed (Knapel, 2012). It is unknown whether consumers consider this faux retro example to actually be retro. If scholars can discover what makes something retro to the consumer, along with what aspects of retro evoke the most positive feelings or even change behavior the most, practitioners could benefit a great deal from the research. The last direction that scholars could take would assist in deciphering consumers' feelings towards retro branding by creating a type of measurement.

Additionally, it would be beneficial to examine how effective various retro marketing practices are and relatedly, to understand the degree to which retro is incorporated into various specific marketing tactics across organizations. Ideally, this avenue of research would require the construction of a scale that assesses the "retroness" of a marketing offering. Engaging in 
focus groups or in-depth interviews with sport consumers, specifically comparing consumers of different ages, levels of team identification, and attachment to their teams, to uncover what makes something retro and creating items for a measurement scale could be a significant addition to the body of knowledge. The scale could assess each practical area as there would be different aspects to examine for the five areas. Imagery would need to examine the color scheme and lettering, among other aspects, and merchandising would be extremely similar but could also examine the packaging and actual material if it is a purchased piece of apparel. Venue would consider the types of banners put up as well as the aims and usage of a hall of fame or ring of honor. The gameday promotions could examine the main purpose of the promotion, as well as the similar aspects of imagery. Last, the advertising aspects could consider the time they are referencing and if it is a successful time, among other aspects. From there, this scale could be connected to consumer' attitudes, emotions, and even behavior to determine how retro marketing impacts the individual sport consumer.

Creating a way to measure retro would be helpful to quantify the impact that it has on consumers. Another reason a measurement would benefit this research would be to determine if "faux" retro like the Tampa Bay Rays used is considered retro and impacts the consumer the same as traditional retro marketing (Knapel, 2012). It will be interesting to discover if sport teams can effectively use retro marketing without having a very long or successful history. A measurement could determine if retro marketing in sport hinges more on the aspects of the practice or the cognitive connection fans have with the past of their favorite teams and leagues. This scale would also be beneficial in examining what impact retro marketing may have on the attitudes, identification, purchase intentions, and actual behaviors of the fans. Retro marketing scholars have focused on the impact that nostalgia has on advertisements (Muehling \& Sprott, 2004; Pascal et al., 2002; Phau \& Marchegiani, 2011) and the consumers' attitudes towards nostalgic products (Brown et al., 2003; Sierra \& McQuitty, 2007). Retro marketing has been found, especially via nostalgic impact, to be a successful marketing tool, and the numerous outlets sport offers for retro marketing should expand the research on retro marketing and consumer behavior.

As the first attempt at categorizing retro marketing in sport, this study's purpose was not only to create a model that explained and categorized the retro marketing practices utilized in sport, but also to establish a potential line of research on the topic. The authors have presented the five practical areas of retro marketing in sport through an inductive approach that led to the categories: imagery, merchandising, venue, gameday promotions, and advertising. Additionally, the authors have presented many directions for future research on retro marketing in sport. Sport is an incredibly unique field and must be examined as such. As teams and leagues rely heavily on retro marketing, scholars should begin to empirically examine how retro marketing impacts sport. The five practical areas of retro marketing in sport should be used as the foundation and guide for future research in this field.

\section{References}

\#FlashbackFriday games and final regular season home game. (2016, February 17). NBA.com. Retrieved from http://www. nba.com/kings/news/kings-use-retro-court

100 years of champions. PAC-12. Retrieved from http://pac-12. com/centennial

About the Australian Hall of Fame. (n.d.). AFL. Retrieved from http://www.afl.com.au/news/event-news/hall-of-fame/about

About Us. (n.d.) Ebbets Field Flannels Vintage Authentic. Retrieved from http://www.ebbets.com/category/aboutus

Ahn, T., Suh, Y. I., Lee, J. K., Pedersen, P. M. (2012). Sport fans and their teams' redesigned logos: An examinations of the moderating effect of team identification on attitude and purchase intention of team-logoed merchandise. Journal of Sport Management, 27(1), 11-23.

Associated Press. (2017, June 18). Reds honor Pete Rose with statue outside of their stadium. The New York Times. Retrieved from https://www.nytimes.com/2017/06/18/sports/reds-honor-pete-rose-with-statue-outside-their-stadium.html

Bagozzi, R.P. (1986). Principles of marketing management. Chicago: Science Research Associates.

Batcho, K.I. (2013). Nostalgia: The bittersweet history of a psychological concept. History of Psychology. Advanced online publication. doi:10.1037/a0032427

Batcho, K. (1995). Nostalgia: A psychological perspective. Perceptual and Motor Skills, 80, 131-143.

Bauer, H.H., Stokburger-Sauer, N.E., \& Exler, S. (2008). Brand image and fan loyalty in professional team sport: A refined model and empirical assessment. Journal of Sport Management, 22, 205-226.

Bell, J. (2013). U.S. soccer celebrates 100 years. The New York Times. Retrieved from https://goal.blogs.nytimes. com/2013/04/02/u-s-soccer-celebrates-100-years/?_r=1

Belson, K. (2014). Encouraging a walk in the hall of fame. The New York Times. Retrieved from https://www.nytimes. com/2014/10/26/arts/artsspecial/nfl-teams-harness-stadiums-as-museums.html?_r=0

Bitner, M. (1992). The impact of physical surroundings on customers and employees. Journal of Marketing, 56(2), 57-71.

Brown, S. (2013). Retro from the get-go: Reactionary reflections on marketing's yestermania. Journal of Historical Research in Marketing, 5(4), 521-536.

Brown, S. (1999). Retro-marketing: Yesterday's tomorrows, today! Marketing Intelligence \& Planning, 17(7), 363-376.

Brown, S., Kozinets, R., \& Sherry, J. (2003). Teaching old brands new tricks: Retro branding and the revival of brand meaning. Journal of Marketing, 67(3), 19-33.

Cattaneo, E., \& Guerini, C. (2012). Assessing the revival potential of brands from the past: How relevant is nostalgia in retro branding strategies? Journal of Brand Management, 19, 680-687. 
Century, D. (2003). In hip-hop, Unitas and Chamberlain live again. The New York Times. Retrieved from: http://www. nytimes.com/2003/01/05/style/in-hip-hop-unitas-and-chamberlain-live-again.html

Chang, H., Eckman, M., \& Yan, R. (2011). Application of the stimulus-organism-response model to the retail environment: The role of hedonic motivation in impulse buying behavior. The International Review of Retail Distribution and Consumer Research, 21(3), 233-249.

Chi, T. \& Kilduff, P. (2011). Understanding consumer perceived value of casual sportswear: An empirical study. Journal of Retailing and Consumer Services, 18(5) 422-429.

Chippin, A. (2016). Georgetown to unveil Allen Iverson bobblehead. The Score. Retrieved from http://www.thescore.com/ news/1043523

Cho, H., Ramshaw, G., \& Norman, W. C. (2014). A conceptual model for nostalgia in the context of sport tourism: Re-classifying the sporting past. Journal of Sport \& Tourism, 19(2), 145-167.

Cialdini, R., Borden, R., Thorne, A., Walker, M., Freeman, S., \& Sloan, L. (1976). Basking in reflected glory: Three (football) field studies. Journal of Personality and Social Psychology, 34(3), 366-375.

Coakley, J. (2007). Sports in Society: Issues and Controversies (9th ed.). New York, NY McGraw-Hill.

Creamer, C. (2016). Maple Leafs new logo takes traditional turn for centennial. Sportslogos.net. Retrieved from http://news.sportslogos.net/2016/02/02/ maple-leafs-new-logo-takes-traditional-turn-for-centennial/

Dator, J. (2016). Raptors unveil their incredible Toronto Huskies throwback court. SB Nation. Retrieved from http://www.sbnation.com/lookit/2016/11/12/13608974/ raptors-unveil-huskies-court-toronto-nba

DeSeni, J. T. \& Rosenberg, D. (2010). Ethics and Morality in Sport Management (3rd ed.). Morgantown, WV: Fitness Information Technology.

Detroit Lions to feature first retro pricing promotion at Ford Field. (2016, Oct. 10). Detroitlions.com. Retrieved from http:// www.detroitlions.com/news/news-short/article-1/DetroitLions-to-feature-first-retro-pricing-promotion-at-Ford-Field/ ae0b4934-d168-4b3e-b565-5a761c2dcb42

Doherty, A. (2013). Investing in sport management: The value of good theory. SportManagement Review, 16, 5-11.

Ducey, K. (2016, Sept. 19). Miami unveils 'Legend of the U’ throwback jerseys. Sports Illustrated. Retrieved from http://www.si.com/college-football/2016/09/19/ miami-legend-of-the-u-throwback-jerseys-photos

Duke to retire numbers for Redick, Williams. (2007, Jan. 11). ESPN.com. Retrieved from http://www.espn.com/espn/wire/_/ section/ncb/id/2728247

Emerick, T. (2016). ESPN Ranks Phoenix Suns retro giveaway in the top 5 of NBA. NBA.com. Retrieved from http://www.nba. com/suns/blog/espn-ranks-suns-giveaway-top-5-nba

Eroglu, S. A., Machleit, K. A., \& Davis, L. M. (2001). Atmospheric qualities of online retailing a conceptual model and implications. Journal of Business Research, 54, 177-184.

Express announce 2016 promotional schedule. (2016, Apr. 25). Northwoodsleague.com. Retrieved from http:// northwoodsleague.com/eau-claire-express/2016/04/25/ express-announce-2016-promotional-schedule/

Fairley, S. (2003). In search of relived social experience: Groupbased nostalgia sport tourism. Journal of Sport Management, 17, 284-304.

Fincher, C. (2015). Suns new marketing campaign rooted in connection to community. Cronkite News. Retrieved from https://cronkitenews.azpbs.org/2015/10/30/ suns-new-marketing-campaign-rooted-in-connection-to-community/

Five statues of Arsenal legends adorn Emirates Stadium. (2017, June 1). Arsenal history. Retrieved from https://www.arsenal. com/arsenal-history/arsenal-s-heritage/arsenal-statues

Frank Howard to be inducted into Nationals ring of honor on Friday, August 26. (2016, Aug. 23). Nationals News. Retrieved from http://m.nationals.mlb.com/news/article/213996890/ nationals-have-closer-bench-choices-to-make/

Funk, D. C., \& James, J. D. (2006). Consumer loyalty: The meaning of attachment in the development of sport team allegiance. Journal of Sport Management, 20, 189-217.

Funk, D. C., \& James, J. (2001). The psychological continuum model: A conceptual framework for understanding an individual's psychological connection to sport. Sport Management Review, 4(2), 119-150.

Funk, D. C., \& Pastore, D. (2000). Equating attitudes to allegiance: The usefulness of selected attitudinal information in segmenting loyalty to professional sports teams. Sport Marketing Quarterly, 9(4), 175-184.

Gladden, J. M., \& Funk, D. C. (2002). Developing an understanding of brand associations in team sport: Empirical evidence from consumers of professional sport. Journal of Sport Management, 16, 54-81.

Golden State Warriors unveil new logo, color scheme and branding elements. (2010, Jun. 17). Retrieved from http://www.nba. com/warriors/news/warriors_unveil_new_logo_061710.html

Gordon, K. O. (2013). Emotion and memory in nostalgia sport tourism: examining the attraction to postmodern ballparks through an interdisciplinary lens. Journal of Sport \& Tourism, 18(3), 217-239.

Green Bay Packers gear. (n.d.). Retrieved from http://www. nflshop.com/Green_Bay_Packers_Throwback_Jerseys

Hill, D. (2017). Tampa Bay Rays to wear throwback uniforms for doubleheader. Fansided. Retrieved from https:// rayscoloredglasses.com/2017/06/07/tampa-bay-rays-wearthrowback-uniforms-doubleheader/

Holbrook, M. (1993). Nostalgia and consumption preferences: Some emerging patterns of Consumer tastes. Journal of Consumer Research, 20(2), 245-256.

Hoye, R., Smith, A., Nicholson, M., \& Stewart, B. (2015). Sport Management: Principles and Applications (4th ed.). New York, N.Y.: Routledge.

Hunt, K. A., Bristol, T., \& Bashaw, R. E. (1999). A conceptual approach to classifying sports fans. Journal of Services Marketing, 13(6), 439-452.

Hunt, L., \& Johns, N. (2013). Image, place, and nostalgia in hospitality branding and marketing. Worldwide Hospitality and Tourism Themes, 5(1), 14-26.

Hurley, M. (2015, Jun. 11). The 10 most embarrassing banners in sports. CBS Boston. Retrieved from http://boston.cbslocal.com/2015/06/11/ top-10-most-embarrassing-banners-in-sports/

Jacksonville Jaguars Gear. (n.d.). NFL shop. Retrieved from http:// www.nflshop.com/Jacksonville_Jaguars_Vintage_Clothing

James, J. (2001). The role of cognitive development and socialization in the initial development of team loyalty. Leisure Science, $23,233-262$.

James, J. \& Kolbe, R. (2000). An identification and examination of influences that shape the creation of a professional team fan. International Journal of Sports Marketing \& Sponsorship, 2(1), 23-35.

JR. (2012). I am a Celtic (at least for now). Celtics Life. Retrieved from http://www.celticslife.com/2012/03/todays-video-i-amceltic-at-least-for.html 
Kamin, B. (2017). Camden Yards paved a retro revolution-and influenced Wrigley Field's renovations. Chicago Tribune. Retrieved from http://www.chicagotribune.com/sports/baseball/ ct-camden-yards-wrigley-field-spt-0504-20170503-story.html

Keller, K. (1993). Conceptualizing, measuring, managing customer-based brand equity. Journal of Marketing, 57, 1-22.

Klopman, M. (2011). NBA forever video: TNT opens basketball season with amazing intro. Huffington Post. Retrieved from http://www.huffingtonpost.com/2011/12/25/nba-forever-video-tnt-intro_n_1169457.html

Knapel, R. (2012). Tampa Bay Rays' "fake” throwbacks and MLB's ugliest novelty uniforms. Bleacher Report. Retrieved from http://bleacherreport.com/articles/1231498-tampa-bay-raysfake-throwbacks-and-mlbs-5-most-hideous-novelty-unifo

Liu, J. (2011). Sports merchandising, publicity rights, and the missing role of the sports fan. Boston College Law Review, 52(2), 493-516.

Lukas, P. (2015). Packers, Dolphins get high marks for throwback uniforms. ESPN.com. Retrieved from http://espn.go.com/nfl/story/_/id/13339342/ packers-dolphins-get-high-marks-throwback-uniforms-nfl

McGuire, J. (2016). Pirates party like it's 1979 with funky, fantastic throwback uniforms. SportingNews. Retrieved from http:// www.sportingnews.com/mlb-news/4702328-pirates-throwback-uniforms-we-are-family-1979-willie-stargell

Merchant, A., \& Rose, G. (2013). Effects of advertising-evoked vicarious nostalgia on brand heritage. Journal of Business Research, 66, 2620-2624.

Mirtle, J. (2016). Maple Leafs ask fans to stand witness with sleek new campaign. The Globe and Mail. Retrieved from http://www.theglobeandmail.com/sports/hockey/leafsask-fans-to-stand-witness-with-sleek-new-campaign/ article32364504/

Muehling, D. D., \& Sprott, D. E. (2004). The power of reflection: an empirical examination of nostalgia advertising effects. Journal of Advertising, 33(3), 25-35.

Mullin, B., Hardy, S., \& Sutton, W. (2014). Sport Marketing (4th ed.). Champaign, IL: Human Kinetics.

Neveau, J. (2015). Cubs announce plans for celebrating 100 years at Wrigley. NBC Chicago. Retrieved from http://www. nbcchicago.com/news/local/Cubs-Announce-Plans-for-Celebrating-100-Years-at-Wrigley--341220432.html

New York Rangers official shop. (n.d.). Retrieved from http://shop. nhl.com/New_York_Rangers_Jerseys_Throwback

NHL Public Relations (2016). NHL unveils 2017 centennial celebrations. NHL.com. Retrieved from https://www.nhl.com/ news/2017-nhl-centennial-plans-announced/c-282175554

Our Story. (n.d.). Nostalgia Co. Mitchell \& Ness. Retrieved from https://www.mitchellandness.com/company/story/

Pascal, V., Sprott, D., \& Muehling, D. (2002). The influence of evoked nostalgia on consumers' responses to advertising: An exploratory study. Journal of Current Issues and Research in Adverting, 24(1), 39-49.

Park, C. W., Eisingerich, A. B., Pol, G., \& Park, J. W. (2013). The role of brand logos in firm performance. Journal of Business Research, 66, 180-187.

Phau, I., \& Marchegiani, C. (2011). The value of historical nostalgia for marketing management. Marketing Intelligence \& Planning, 29(2), 108-122.

Premier league kits: Man Utd, Arsenal \& all the new jerseys for 2017-2018. (2017, July 25). Goal. Retrieved from http://www. goal.com/en us/news/85/england/2017/07/25/35869302/ premier-league-kits-man-utd-arsenal-all-the-new-jerseysfor-2017-
Ramshaw, G., \& Gammon, S. (2005). More than just nostalgia? Exploring heritage/sport tourism nexus. Journal of Sport Tourism, 10(4), 229-241.

Retro Soccer Gear (n.d.). World Soccer Shop. Retrieved from http://www.worldsoccershop.com/shop/departments/ retro-soccer-gear/

Ross, S. D., James, J. D., \& Vargas, P. (2006). Development of a scale to measure team brand associations in professional sports. Journal of Sport Management, 20, 260-279.

Royals Retro Pricing-Sept 15-18. (2018). Royals.com. Retrieved from http://kansascity.royals.mlb.com/kc/ticketing/retro_pricing.jsp

Sara, A. (2016). Watch: Suns release early hype video to promote "WeArePHX" campaign. ClutchPoints. Retrieved from http:// clutchpoints.com/watch-suns-release-early-hype-video-promote-wearephx-campaign/

Sedikides, C., Wildschut, T., Arndt, J., \& Routledge, C. (2008). Nostalgia past, present, and future. Current Directions in Psychological Science, 17(5), 304-307.

Seifried, C., \& Meyer, K. (2010). Nostalgia-related aspects of professional sport facilities: A facility audit of Major League Baseball and National Football League strategies to evoke the past. International Journal of Sport Management Recreation and Tourism, 5, 51-76.

Sherman, E., Mathur, A., \& Smith, R. B. (1997). Store environment and consumer purchase behavior: Mediating rode of consumer emotions. Psychology \& Marketing, 14(4), 361-378.

Should Boston Celtics un-retire some numbers? (2015, August 3). Fox Sports. Retrieved from http://www.foxsports.com/nba/ story/should-boston-celtics-un-retire-some-numbers-080315

Sierra, J., \& McQuitty, S. (2007). Attitudes and emotions as determinants of nostalgia purchases: An application of social identity theory. Journal of Marketing Theory and Practice, 15(2), 99-112.

Snyder, M. (2016). Look: Mets to wear 1986 throwback jerseys as alternates this season. CBS Sports. Retrieved from http://www. cbssports.com/mlb/eye-on-baseball/25472488/look-mets-towear-1986-throwback-jerseys-throughout-the-season

Snyder, M. (2016). Ranking the best of the 2016 MLB ballpark promotions. CBS Sports. Retrieved from http://www.cbssports.com/mlb/news/ ranking-the-best-of-the-2016-mlb-ballpark-promotions/

Staff Writer. (2016). Ohlund to be inducted into Ring of Honour. Canucks News. Retrieved from https://www.nhl.com/canucks/ news/ohlund-to-be-inducted-into-ring-of-honour/c-887112

Stern, B. (1992). Historical and personal nostalgia in advertising text: The fin de siècle effect. Journal of Advertising, 21(4), $11-22$.

Stride, C. B., Wilson, J. P., \& Thomas, F. (2013) Honouring heroes by bronze: theorizing the UK's football statuary. Sport in Society, 16(6), 749-771.

Tajfel, H., \& Turner, J. (1979). An integrative theory of intergroup conflict. The social psychology of intergroup relations, 33(47), 74 .

Thomas, D. (2006). A general inductive approach for qualitative data analysis. American Journal of Evaluation, 27, 237-246.

Trail Blazers flashback to 1977 with 40th anniversary of NBA championship during January 25 game vs. Lakers. (2017, Jan. 13). NBA.com. Retrieved from http://www.nba.com/blazers/ trail-blazers-flashback-1977-40th-anniversary-nba-championship-during-january-25-game-vs-lakers/

Uhrich, S., \& Koenigstorfer, J. (2009). Effects of atmosphere at major sports events: a perspective from environmental psychology. International Journal of Sports Marketing \& Sponsorship, 10(4), 56-75. 
Vieira, V. A. (2013). Stimuli-organism-response framework: A meta-analytic review in the store environment. Journal of Business Research, 66, 1420-1426.

Wakefield, K., \& Blodgett, J. (1994). The importance of servicescapes in leisure service settings. Journal of Services Marketing, 10(6), 45-61.

Watkins, B. (2014) Revising the social identity-brand equity model: An application to professional sports. Journal of Sport Management, 28, 471-480.

Whitaker, L. (2015) Warriors unveil throwback uniforms, court on NBA TV. ALLBALL. Retrieved from http://allball.blogs. nba.com/2015/11/17/warriors-unveil-throwback-uniformscourt-tonight-on-nba-tv/

Wildschut, T., Sedikides, C., Arndt, J., \& Routledge, C. (2006). Nostalgia: Content, triggers, functions. Journal of Personality and Social Psychology, 91(5), 975-993.

Yellon, A. (2016). Cubs announce 2016 promotional schedule, including 1916 throwback jersey. Bleedcubbieblue. Retrieved from http://www.bleedcubbieblue.com/2016/2/25/11113084/ cubs-2016-promotional-schedule-1916-throwback-jersey

Young, L. (2016). Mariners v. Cardinals turn back the clock night. Seattle pi. Retrieved from http://www.seattlepi.com/ photos/slideshow/Marines-v-Cardinals-Turn-Back-the-ClockNight-131525.php

Young, R. (2013). Adidas unveils seven 1990s retro jerseys. CBS Sports. Retrieved from http://www. cbssports.com/nba/eye-on-basketball/21628216/ adidas-unveils-six-1990s-retro-jerseys

Zhao, G., Li, W., Teng, L., \& Lu, T. (2014). Moderating role of consumer self-concept on the effectiveness of two nostalgia appeals. Journal of Promotion Management, 20, 1-19. 
Copyright of Sport Marketing Quarterly is the property of Fitness Information Technology, Inc. and its content may not be copied or emailed to multiple sites or posted to a listserv without the copyright holder's express written permission. However, users may print, download, or email articles for individual use. 